\title{
Effects of an eco-silica source based activator on functional alkali activated lightweight composites
}

\section{Citation for published version (APA):}

Gao, X., \& Yu, Q. (2019). Effects of an eco-silica source based activator on functional alkali activated lightweight composites. Construction and Building Materials, 215, 686-695.

https://doi.org/10.1016/j.conbuildmat.2019.04.251

\section{Document license:}

TAVERNE

DOI:

10.1016/j.conbuildmat.2019.04.251

Document status and date:

Published: 10/08/2019

\section{Document Version:}

Publisher's PDF, also known as Version of Record (includes final page, issue and volume numbers)

\section{Please check the document version of this publication:}

- A submitted manuscript is the version of the article upon submission and before peer-review. There can be important differences between the submitted version and the official published version of record. People interested in the research are advised to contact the author for the final version of the publication, or visit the $\mathrm{DOI}$ to the publisher's website.

- The final author version and the galley proof are versions of the publication after peer review.

- The final published version features the final layout of the paper including the volume, issue and page numbers.

Link to publication

\section{General rights}

Copyright and moral rights for the publications made accessible in the public portal are retained by the authors and/or other copyright owners and it is a condition of accessing publications that users recognise and abide by the legal requirements associated with these rights.

- Users may download and print one copy of any publication from the public portal for the purpose of private study or research.

- You may not further distribute the material or use it for any profit-making activity or commercial gain

- You may freely distribute the URL identifying the publication in the public portal.

If the publication is distributed under the terms of Article 25fa of the Dutch Copyright Act, indicated by the "Taverne" license above, please follow below link for the End User Agreement:

www.tue.nl/taverne

Take down policy

If you believe that this document breaches copyright please contact us at:

openaccess@tue.nl

providing details and we will investigate your claim. 


\title{
Effects of an eco-silica source based activator on functional alkali activated lightweight composites
}

\author{
X. Gao ${ }^{\mathrm{a}}$, Q.L. Yu ${ }^{\mathrm{b}, *}$ \\ ${ }^{a}$ School of Civil Engineering and Architecture, Wuhan University of Technology, Wuhan 430070, PR China \\ ${ }^{\mathrm{b}}$ Department of the Built Environment, Eindhoven University of Technology, P.O. Box 513, 5600 MB Eindhoven, The Netherlands
}

\section{H I G H L I G H T S}

- Eco-friendly functional alkali-activated lightweight composites are developed.

- Effect of eco-silica source on alkali activation and carbon footprints is assessed.

- Effect of alkali activator on acoustical property is studied.

- Relationship between thermal conductivity and density is derived.

- Effect of alkali content on compressive strength is evaluated.

\section{A R T I C L E I N F O}

\section{Article history:}

Received 22 November 2018

Received in revised form 8 March 2019

Accepted 27 April 2019

\section{Keywords:}

Alkali activation

Lightweight aggregate composites

Eco-nano-silica

Thermal properties

Acoustic absorption

Carbon emission

\begin{abstract}
A B S T R A C T
In this paper, alkali activated slag-fly ash lightweight composites with moderate densities between around 1200 and $1500 \mathrm{~kg} / \mathrm{m}^{3}$ are prepared and characterized. An eco-olivine nano-silica is applied to prepare sustainable silicate based activators to replace commercial sodium silicates. $\mathrm{Na}_{2} \mathrm{O}$ contents of 2.0 , 3.5 and $5.0 \mathrm{wt} \%$ are investigated in order to reach a suitable balance between performance, costs and application. The results show the positive effect of density and $\mathrm{Na}_{2} \mathrm{O}$ content on strength, while strength increment between $\mathrm{Na}_{2} \mathrm{O}$ dosage of $3.5 \%$ and $5.0 \%$ is limited. The reduction of $\mathrm{Na}_{2} \mathrm{O}$ content shows a dramatic delay of the reaction process up to around $3 \mathrm{~d}$, but shows negligible effect on the typical Si-O bonds. An increased $\mathrm{Na}_{2} \mathrm{O}$ content benefits the formation of reaction products, including the contents of hydrotalcite and carbonates. Besides, the thermal conductivity and acoustical absorption properties of the lightweight products are characterized; the phase transition zones between lightweight aggregate and binder matrix are evaluated by SEM. The calculation on the carbon footprint shows an evident advantage of using alkali activated materials to replace Portland cement, also the utilization of olivine nano-silica further reduces the carbon emission of the activator by around $25 \%$.
\end{abstract}

(c) 2019 Elsevier Ltd. All rights reserved.

\section{Introduction}

Lightweight concrete has been widely applied as both structural and non-structural components in a wide range of weights and strengths for various applications [1,2], due to its properties such as low density, good thermal insulation and fire resistance [3]. Lightweight concrete can be categorized into three grades in general, depending on the density: low density ones with densities lower than $800 \mathrm{~kg} / \mathrm{m}^{3}$, moderate ones with densities between $800 \mathrm{~kg} / \mathrm{m}^{3}$ and $1400 \mathrm{~kg} / \mathrm{m}^{3}$ and structural ones with densities between $1400 \mathrm{~kg} / \mathrm{m}^{3}$ and $2000 \mathrm{~kg} / \mathrm{m}^{3}$ [4]. In addition, Portland cement is commonly used as binding material for lightweight con-

\footnotetext{
* Corresponding author.

E-mail address: q.yu@bwk.tue.nl (Q.L. Yu).
}

crete, but its production is responsible for around $7 \%$ of the global carbon emissions and high energy costs $[5,6]$. In order to reduce the negative environmental impacts, the development of sustainable alternatives such as alkali activated materials has been investigated because of the excellent mechanical properties, durability, thermal resistance together with low energy and carbon costs [79]. Some efforts have also been spent on applying alkali activated materials in producing lightweight products; including for instance the study of design methodologies of ultra-lightweight geopolymers by applying the particle packing approach, the effect of key factors such as suitable ratios between binder, activator and aggregates [10]; the development of lightweight geopolymers with foaming agent especially for thermal insulating properties [11]; investigating the relations between density, mechanical properties and thermal conductivity of geopolymers with medium to low 
densities [12-14]; the utilization of different alkali binders and unconventional aggregates [15-17].

In terms of the alkali activated binders, they are usually produced by mixing alkaline activator solutions with solid precursors, and two typical binding systems can be classified: one is the Si and Ca enriched system, having a chain structured C-A-S-H type gel as main reaction product [18]; another is the $\mathrm{Si}+\mathrm{Al}$ system, the reaction product is mainly a three-dimensional N-A-S-H network [19]. Recently, the blended alkaline system, which is a mixed binder system that combines two types of typical binders together, has received increased attention due to the modified properties such as setting times, workability, shrinkage, mechanical properties and durability [20-23]. Synthesizing factors that are related to key performances of blended system such as activator and raw materials' parameters, curing conditions on reaction kinetics, gel characters, mechanical properties and durability issues have been widely studied [24-28]. Those understandings make this type of material a brighter future to applications.

In alkali activated materials, the activator plays an important role on the activation process by providing necessary alkalinities for the decomposition of raw materials and formation of reaction products. The commonly used activators are alkali hydroxides, silicates, carbonates, sulfates, aluminates or oxides; and it is widely accepted that silicate based ones $\left(\mathrm{M}_{2} \mathrm{O} \cdot \mathrm{nSiO} \mathrm{O}_{2}+\mathrm{MOH}\right)$ usually result in ideal mechanical properties and relatively low porosity $[18,29]$. The silicate based activator exhibits advantages by providing the alkaline environment continuously and moderately, also the additionally provided silicates from the activator will participate into the reaction products and lead to a refined microstructure [30], and sufficient content of $\mathrm{M}_{2} \mathrm{O}$ promotes the activation efficiency while exceeding dosage show limited further contribution. However, the primary drawback of silicate based activators is its negative environmental impact. The commercial process of sodium silicate production includes the melting of sodium carbonate and quartz sand around $1400-1500{ }^{\circ} \mathrm{C}$ with carbon release of above $400 \mathrm{~kg} /$ ton [31]. In order to achieve a more eco-friendly binder system, a green olivine nano-silica is applied as alternative silica source to prepare activator solutions in this study. The olivine nano-silica is produced by dissolving olivine stone in acid under temperatures lower than $95{ }^{\circ} \mathrm{C}$, and this process shows advantages in carbon emission, energy consumption and total costs [32]. Therefore an alkali activated product with further reduced overall environmental impacts can be expected.

The objective of this study is to evaluate an eco-silicate source based alkali activator in designing lightweight composites, using blended alkali activated binder. The binder materials are chosen to be ground granulated blast furnace slag and class F fly ash due to their worldwide availability and relatively stable properties, and the lightweight aggregate is based on a natural expanded silicate. The lightweight composites are designed with the aim to have moderate densities together with excellent mechanical, thermal and acoustic properties. Special focuses are paid on the efficient usage of activators and the effect of alkaline conditions on the lightweight aggregate, because the silica based, porous structure of lightweight aggregate would show an interaction with the pastes due to either dissolution of silica or absorption of activator solution. The effect of activator dosages, addition of lightweight aggregates on early age reaction, gel structure, and aggregatesbinder transition zones are investigated by using isothermal calorimeter, Thermo-gravimeter (TG), Fourier transform infrared spectroscopy (FITR) and Scanning electron microscopy (SEM) analysis. The mechanical properties, thermal conductivity and sound absorption properties are evaluated and the effect of the alkali content on these properties is investigated.

\section{Experiment}

\subsection{Materials}

The powder raw materials applied in the present work are blast furnace slag and Class F fly ash, and their major chemical compositions are shown in Table 1. Commercial lightweight aggregates produced from natural expanded silicate with three particle sizes are applied: $0.5-1 \mathrm{~mm}, 1-2 \mathrm{~mm}$ and $2-4 \mathrm{~mm}$, with particle densities of 600,550 and $500 \mathrm{~kg} / \mathrm{m}^{3}$, respectively. CEN standard sand is also used as fine aggregate. The SEM pictures of the lightweight aggregates' surface and internal structure are provided in Fig. 9(A and B). Analytical sodium hydroxide and laboratory prepared olivine nano-silica ( $19.04 \% \mathrm{SiO}_{2}$ and $80.96 \% \mathrm{H}_{2} \mathrm{O}$ by mass) were used to produce alkali activators. The olivine nano-silica was produced by dissolving olivine in acid at low temperatures, followed by a washing and filtering process [33,34]. Desired activator parameters were obtained by mixing calculated dosage of sodium hydroxide, olivine nano-silica and distilled water.

\subsection{Sample preparation}

Three levels of equivalent $\mathrm{Na}_{2} \mathrm{O}$ content were used in this study: $2.0 \%, 3.5 \%$ and $5.0 \%$ (by mass of the binder). A fixed activator modulus of 1.4 and a slag/fly ash mass ratio of $8 / 2$ were used based on the previous experiences [35,36]. Mixtures are designed to have oven dry densities between 1200 and $1500 \mathrm{~kg} / \mathrm{m}^{3}$, i.e. within the density class of D1,4 and D1,6 according to EN 206-1 [70]. The detailed mix proportions are presented in Table 2, for instance, sample with the label of D15-5.0 means it was designed to have a density level of $1500 \mathrm{~kg} / \mathrm{m}^{3}$ and a $\mathrm{Na}_{2} \mathrm{O}$ content of $5.0 \%$. Specimens were prepared and poured into molds of $40 \times 40 \times 160 \mathrm{~mm}^{3}$, then covered with a plastic film to prevent the moisture loss. All specimens were demolded after $24 \mathrm{~h}$ of curing and cured at room temperature and a relative humidity of $95 \%$ until testing age.

\subsection{Testing methods}

The compressive strength was determined according to EN 1961 [37]. Samples were tested at the ages of 7 and $28 \mathrm{~d}$, respectively. The early age hydration heat release was investigated by an isothermal calorimeter with TAM Air, Thermometric. Measurements were carried out for $72 \mathrm{~h}$ under a constant temperature of $20^{\circ} \mathrm{C}$. Fourier transform infrared spectroscopy (FTIR) study was conducted in a Varian 3100 instrument with a resolution of $1 \mathrm{~cm}^{-1}$, and the applied wavenumbers were between 4000 and $600 \mathrm{~cm}^{-1}$. The thermal analyses were performed in a STA $449 \mathrm{~F} 1$ instrument; the testing temperatures were up to $1000^{\circ} \mathrm{C}$ with an increment of $5{ }^{\circ} \mathrm{C} / \mathrm{min}$, protected by nitrogen gas. The thermal conductivity (k) and the mass heat capacity (c) were measured by

Table 1

Major chemical composition of slag and fly ash.

\begin{tabular}{lll}
\hline Oxides (wt.\%) & FA & GGBS \\
\hline $\mathrm{SiO}_{2}$ & 54.62 & 34.44 \\
$\mathrm{Al}_{2} \mathrm{O}_{3}$ & 24.42 & 13.31 \\
$\mathrm{CaO}$ & 4.44 & 37.42 \\
$\mathrm{MgO}$ & 1.43 & 9.89 \\
$\mathrm{Fe}_{2} \mathrm{O}_{3}$ & 7.21 & 0.47 \\
$\mathrm{Na}_{2} \mathrm{O}$ & 0.73 & 0.34 \\
$\mathrm{~K}_{2} \mathrm{O}$ & 1.75 & 0.47 \\
$\mathrm{SO}_{3}$ & 0.46 & 1.23 \\
$\mathrm{LOI}$ & 2.80 & 1.65 \\
\hline
\end{tabular}


Table 2

Mix proportions of alkali-activated slag-fly ash composites $\left(\mathrm{kg} / \mathrm{m}^{3}\right)$.

\begin{tabular}{|c|c|c|c|c|c|c|c|c|c|}
\hline \multirow[t]{2}{*}{ Sample } & \multicolumn{2}{|c|}{ Precursors } & \multicolumn{3}{|c|}{ Activator } & \multirow{2}{*}{$\begin{array}{l}\text { Sand } \\
0-2\end{array}$} & \multicolumn{3}{|c|}{ Lightweight aggregates } \\
\hline & Slag & Fly ash & Nano-s & $\mathrm{NaOH}$ & $\mathrm{H}_{2} \mathrm{O}$ & & $2-4$ & $1-2$ & $0.5-1$ \\
\hline D15-5.0 & 384 & 96 & 170.8 & 30.9 & 77.7 & 370 & 200 & 150 & 30 \\
\hline D15-3.5 & 384 & 96 & 119.6 & 21.7 & 119.1 & 380 & 200 & 150 & 30 \\
\hline D15-2.0 & 384 & 96 & 68.3 & 12.4 & 170.7 & 390 & 200 & 150 & 30 \\
\hline D12-5.0 & 384 & 96 & 170.8 & 30.9 & 77.7 & 0 & 240 & 180 & 30 \\
\hline D12-3.5 & 384 & 96 & 119.6 & 21.7 & 119.1 & 10 & 240 & 180 & 30 \\
\hline D12-2.0 & 384 & 96 & 68.3 & 12.4 & 170.7 & 20 & 240 & 180 & 30 \\
\hline D14-3.5 & 384 & 96 & 119.6 & 21.7 & 119.1 & 260 & 230 & 140 & 30 \\
\hline D13-3.5 & 384 & 96 & 119.6 & 21.7 & 119.1 & 135 & 245 & 150 & 30 \\
\hline
\end{tabular}

using a heat transfer analyser (ISOMET 2104) [38]. The acoustic absorption coefficient was measured according to EN 10534-2 [39]. Microstructure of the reaction products was identified by scanning electron microscopy (SEM) using a JEOL JSM-IT100 instrument, operated with high vacuum mode at an accelerating voltage of $10 \mathrm{kV}$.

\section{Results and discussion}

\subsection{Compressive strength}

The 7 and $28 \mathrm{~d}$ compressive strength of mixtures with different density levels and $\mathrm{a}_{2} \mathrm{O}$ content of $3.5 \%$ are shown in Fig. 1 . The relations between the oven dry density and strength are briefly depicted. It can be seen that as the density decreases, there is an obvious reduction in strength at both 7 and $28 \mathrm{~d}$. The highest 28 d strength reaches $30.7 \mathrm{MPa}$ in mixtures with a density of $1471 \mathrm{~kg} / \mathrm{m}^{3}$, and it gradually reduces to $20.6 \mathrm{MPa}$ in samples with a density of $1163 \mathrm{~kg} / \mathrm{m}^{3}$. The relation between density and strength in this study is in line with previous studies concerning the lightweight aggregate based composites [40-44], while the strength results shown here are higher in general than the alkali activated lightweight composites reported in literatures [45-47]. Considering the fact that those mixtures are having the same binder content, the reduced compressive strength is mainly attributed to the replacement of normal sand by lightweight aggregates (as shown in Table 2), and a less overall capacity of the aggregates against compressive loading is resulted. The $7 \mathrm{~d}$ strengths share a

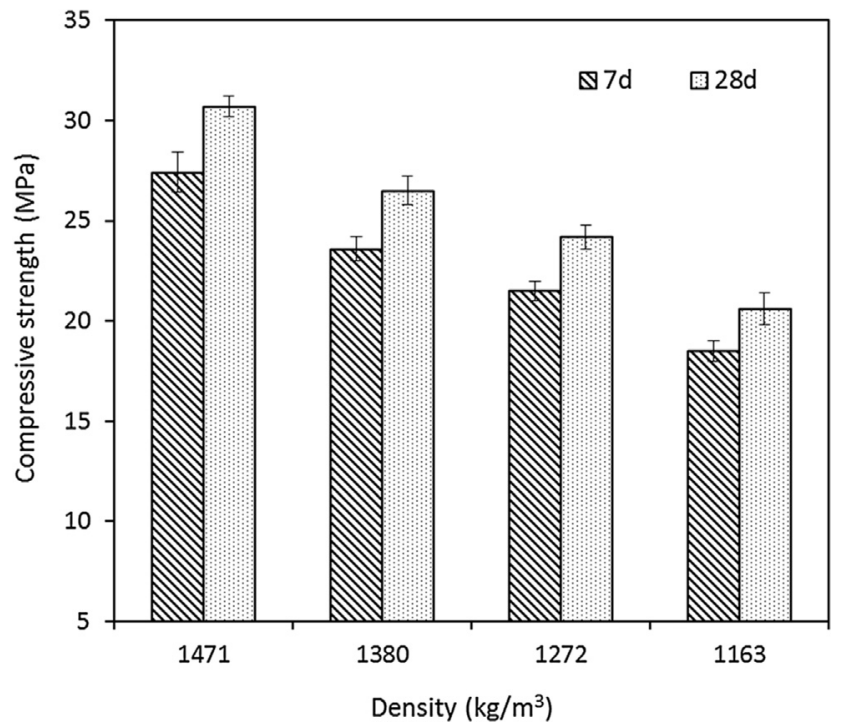

Fig. 1. Compressive strength of AA slag-fly ash lightweight composites with different densities. similar tendency with the $28 \mathrm{~d}$ 's, which decreases from $27.4 \mathrm{MPa}$ to $18.5 \mathrm{MPa}$ within the density range of around $1500-1200 \mathrm{~kg} /$ $\mathrm{m}^{3}$. The $7 \mathrm{~d}$ compressive strengths shown in Fig. 1 are all above $88 \%$ of the $28 \mathrm{~d}$ strength. This is because of the nature of the alkali activated binder system and the ceiling effect of the lightweight aggregates, which presents a relatively fast reaction process and exhibits large percent of the strength at early ages $[1,9,35]$. It should be noticed that key parameters such as activator type and dosage, binder composition and fineness, curing conditions also strongly influence the reaction process, and therefore the strength development.

Fig. 2 depicts the effect of the equivalent $\mathrm{Na}_{2} \mathrm{O}$ content on $28 \mathrm{~d}$ compressive strength of mixtures with two density levels: 1500 and $1200 \mathrm{~kg} / \mathrm{m}^{3}$, represented with sample label of D-15 and D-12 in the figure. As stated in the introduction part, the alkali activator contributes to a large fraction of the overall environmental issue of alkali activated materials, thus an efficient usage of the activator is of clear significance. For mixtures with a $\mathrm{Na}_{2} \mathrm{O}$ content of $5 \%$ in this study, the additionally provided silicate from the activator accounts for around $14.9 \%$ of the total silicate within the system, and this activator dosage is commonly used in achieving a high strength $[9,20,21,24-26]$. When reducing the $\mathrm{Na}_{2} \mathrm{O}$ content to $3.5 \%$ and $2.0 \%$, the silicate fraction from the activator decreases to $10.9 \%$ and $6.6 \%$, respectively. Concerning its influence on strength, as can be seen in Fig. 2 that there is an obvious increment of strength when increasing the $\mathrm{Na}_{2} \mathrm{O}$ content from $2.0 \%$ to $3.5 \%$, and the increase of strength exhibits a limited scale when further increasing the $\mathrm{Na}_{2} \mathrm{O}$ content to $5.0 \%$. To specify, in mixtures with

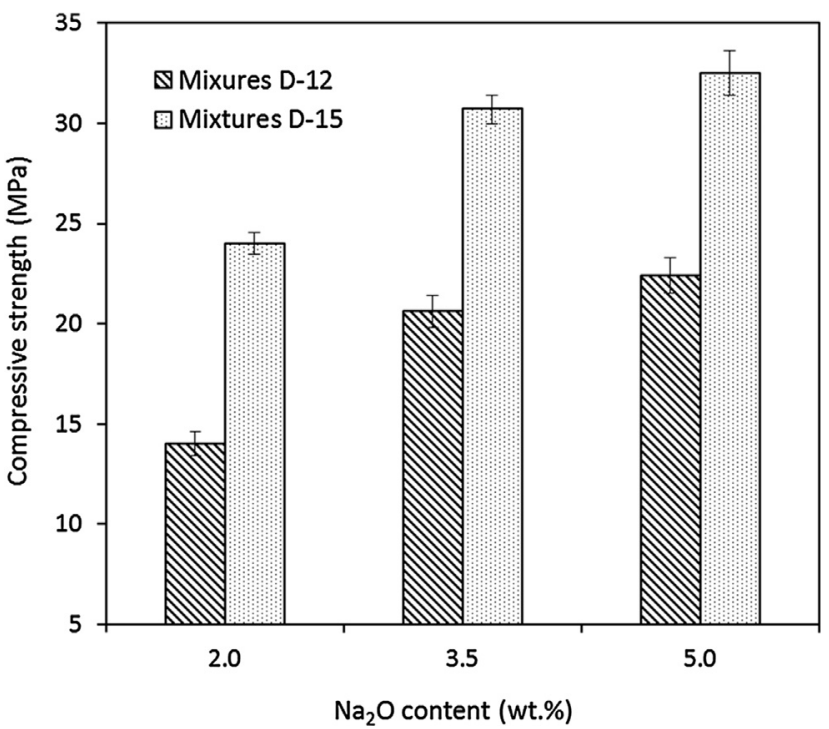

Fig. 2. Compressive strength of AA slag-fly ash lightweight composites with different $\mathrm{Na}_{2} \mathrm{O}$ contents. 
a density level of $1500 \mathrm{~kg} / \mathrm{m}^{3}$, the $28 \mathrm{~d}$ strength is increased from 24.0 MPa to $30.7 \mathrm{MPa}$ when shifting the $\mathrm{Na}_{2} \mathrm{O}$ dosage from $2.0 \%$ to $3.5 \%$, namely a relative increase of $27.9 \%$, and this value is $32.5 \mathrm{MPa}$ in mixtures with a $\mathrm{Na}_{2} \mathrm{O}$ content of $5.0 \%$, with a relative increase of only $5.9 \%$. This phenomenon reveals that both $\mathrm{Na}_{2} \mathrm{O}$ content and density show an important influence on strength. On the one hand, increasing the alkalinity $\left(\mathrm{Na}_{2} \mathrm{O} \%\right)$ will promote the activation of the binder that consequently leads to a higher strength from the aspect of the binder matrix; while on the other hand, the usage of lightweight aggregate limits the strength development by the relatively low crushing strength of the aggregate. Investigating the effect of both density and alkalinity provides insights concerning how the strength would vary within the designed parameter ranges, which also gives information on tailoring the strength with certain densities and reasonable activator dosages for different application requirements.

\subsection{Reaction kinetics}

The isothermal calorimeter test was performed on mixtures with the $\mathrm{Na}_{2} \mathrm{O}$ content of $2.0 \%, 3.5 \%$ and $5.0 \%$, respectively, and lightweight aggregates were added with an aggregate/binder ratio of 0.8 (based on the mixture proportions shown in Table 2), in order to evaluate their effect on the early age reaction. Fig. 3 illustrates the normalized heat flows of samples with and without lightweight aggregates during the first $6 \mathrm{~d}$; the heat flow is normalized by mass of the binder (slag and fly ash). The sample labelled as "LWA-5.0" refer to the one with $\mathrm{Na}_{2} \mathrm{O}$ content of 5.0, and "LWA-5.0 +Agg" means lightweight aggregates are included in the test. It is generally agreed that reaction process of alkali activated materials can be classified into four typical stages $[18,48,49]$ : the initial dissolution period, induction period, acceleration/deceleration period and stable period. The first stage refers to the initial contact of the solid components with liquid solution, and the dissolution of the precursors. The induction period refers to the temporary induction of heat release before the main reaction takes place. The acceleration and deceleration periods are attributed to the massive formation of the reaction products, and the stable period indicates that the main reaction process comes to the end while minor reaction may still occur in the long term.

It can be seen from Fig. 3 that the mixtures with a $\mathrm{Na}_{2} \mathrm{O}$ content of $5 \%$ exhibit a main reaction peak at around $16 \mathrm{~h}$, with a peak intensity of $1.35 \mathrm{~mW} / \mathrm{g}$. The induction stage shows an induction

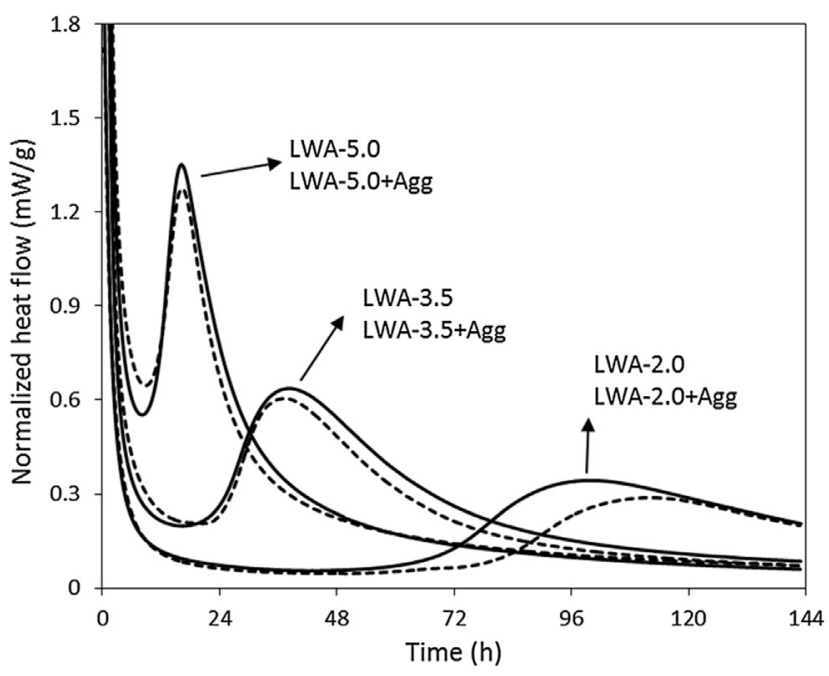

Fig. 3. Normalized heat flows of AA slag-fly ash pastes with different $\mathrm{Na}_{2} \mathrm{O}$ contents and lightweight aggregates. period between around 6 and $10 \mathrm{~h}$, followed by an evident increase of heat flow representing the intensive chemical reaction [50]. When reducing the $\mathrm{Na}_{2} \mathrm{O}$ content to $3.5 \%$, a significantly retarded reaction process can be observed. The induction period appears at around $9-22 \mathrm{~h}$, the beginning of this stage is $3 \mathrm{~h}$ later than the one in sample with a $\mathrm{Na}_{2} \mathrm{O}$ content of $5 \%$, also the duration of this stage is more than 3 times longer. The location of the main reaction peak is also delayed to $37 \mathrm{~h}$, which is $21 \mathrm{~h}$ later than the $5 \% \mathrm{Na}_{2} \mathrm{O}$ mixtures. Besides, the peak intensity is reduced to $0.63 \mathrm{~mW} / \mathrm{g}$ and the deceleration period exhibits a more moderate reduction of heat release. A further lowered $\mathrm{Na}_{2} \mathrm{O}$ dosage of $2.0 \%$ results in a dramatic delay of the reaction process. For instance, the induction period lasts more than $48 \mathrm{~h}$; the main reaction peak exhibits an obviously broader covered area with a low peak intensity of about $0.34 \mathrm{~mW} / \mathrm{g}$, indicating a gradual and slow formation of the reaction products. Until the testing age of $144 \mathrm{~h}$, the deceleration stage is still ongoing. Thus it can be concluded that the reduction of the reaction process does not present a linear relation with the $\mathrm{Na}_{2} \mathrm{O}$ content, the shift of $\mathrm{Na}_{2} \mathrm{O}$ concentration effectively influences the characters of the reaction process such as induction time, reaction intensity, the location and duration of main reaction period. Similar tendencies are also shown in previous researches regarding the effect of activator modulus (usually with a constant $\mathrm{Na}_{2} \mathrm{O}$ dosage) [35,49], while the reduction of peak intensity and the delay of the main reaction process is rather limited compared to the case of this study, which suggests that the activator characters such as additional silicate content and the alkalinity strongly control the activation process of the precursors.

The reaction kinetics results can be correlated to the compressive strength results in this study, where mixtures with a $\mathrm{Na}_{2} \mathrm{O}$ content of $2.0 \%$ show an obviously lower strength than the ones with higher $\mathrm{Na}_{2} \mathrm{O}$ contents. It is concluded that the delayed reaction process together with lower intensities provide a reduced activation on the starting materials, resulting in an overall lower reaction degree and strength. The heat release curves with dash lines refer to the mixtures with lightweight aggregate additions. For mixes with a $\mathrm{Na}_{2} \mathrm{O}$ content of $5.0 \%$, the aggregate incorporation slightly reduces the intensity of the main reaction peak without significant effect on its location, and there is also a very slight delay of the induction period. Similar trends are also shown in samples with $3.5 \% \mathrm{Na}_{2} \mathrm{O}$ content, indicating that the effect of lightweight aggregate on the early age reaction is rather limited, and those slight effects are probably attributed to the absorption of small amount of activator during the initial mixing. Mixes with a $\mathrm{Na}_{2} \mathrm{O}$ content of $2.0 \%$ exhibits an evident delay of the main reaction peak, which indicates that under low alkalinity conditions, the effect of lightweight aggregate (activator absorption) is magnified.

The cumulative heat release of all mixtures is shown in Fig. 4. Differences in heat release processes caused by $\mathrm{Na}_{2} \mathrm{O}$ content and aggregate addition are clearly depicted. Mixtures with a $\mathrm{Na}_{2} \mathrm{O}$ content of 5.0\% present the highest cumulative heat of about $166 \mathrm{~J} / \mathrm{g}$ till the testing age of $144 \mathrm{~h}$. Samples with $3.5 \% \mathrm{Na}_{2} \mathrm{O}$ show a slightly lower heat release of $153 \mathrm{~J} / \mathrm{g}$, while the heat release of mixes with a $\mathrm{Na}_{2} \mathrm{O}$ dosage of $2.0 \%$ is significantly lower: $106 \mathrm{~J} / \mathrm{g}$, which is also partly because that the main reaction process is still processing. When lightweight aggregate is incorporated, similar heat release is shown in $5 \% \mathrm{Na}_{2} \mathrm{O}$ mixtures. Similar to the results shown in Fig. 3, as the $\mathrm{Na}_{2} \mathrm{O}$ content decreases, the effect of lightweight aggregate on heat release becomes more significant.

\subsection{Gel structures}

In order to investigate to the effect of the $\mathrm{Na}_{2} \mathrm{O}$ content on the gel compositions, the TG/DTG and FTIR analyses were performed and the results are shown in Figs. 5 and 6, respectively. Samples with the label of "LWA-2.0" refer to the ones produced with 


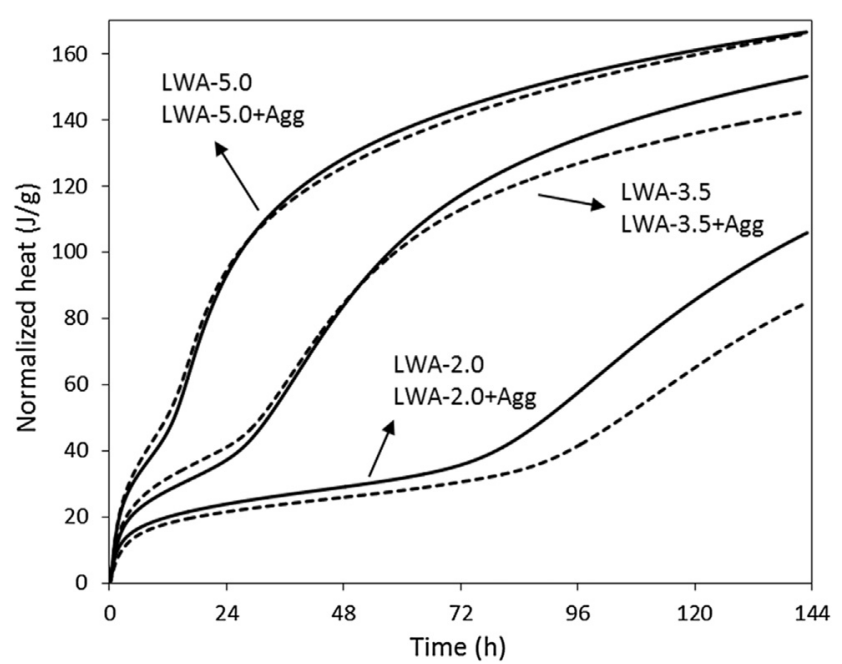

Fig. 4. Normalized heat releases of AA slag-fly ash mortars with different $\mathrm{Na}_{2} \mathrm{O}$ contents and lightweight aggregates.

$\mathrm{Na}_{2} \mathrm{O}$ content of $2.0 \%$. As shown in Fig. 5(a), the mixtures with 3 levels of $\mathrm{Na}_{2} \mathrm{O}$ content exhibit an evident mass loss before around $100{ }^{\circ} \mathrm{C}$, owing to the evaporation of physically bound water. Another significant loss in mass is shown between about 250 and $450{ }^{\circ} \mathrm{C}$, which are attributed to the decomposition of the reaction products. Afterwards, a gradual decrease in mass is presented in general until $1000{ }^{\circ} \mathrm{C}$; while the remarkable mass loss between 600 and $800{ }^{\circ} \mathrm{C}$ is assigned to the decomposition of carbonates [51], indicating that a certain degree of carbonation took place during the curing process. Three mixtures exhibit similar mass loss before $100{ }^{\circ} \mathrm{C}$ (mainly evaporable water), which is $4.9 \%, 4.0 \%$ and $5.3 \%$ for samples with a $\mathrm{Na}_{2} \mathrm{O}$ content of $5.0 \%, 3.5 \%$ and $2.0 \%$, respectively. This value can be slightly influenced by sampling and variations, thus it is difficult to precisely identify the effect of $\mathrm{Na}_{2} \mathrm{O}$ dosage in this mass loss range. The mass loss between 100 and $600{ }^{\circ} \mathrm{C}$, which can be mainly attributed by the decomposition of reaction products, is $8.0 \%$ for mixes with a $\mathrm{Na}_{2} \mathrm{O}$ content of $5.0 \%$. It slightly decreases to $7.4 \%$ in mixes of $3.5 \% \mathrm{Na}_{2} \mathrm{O}$; while this

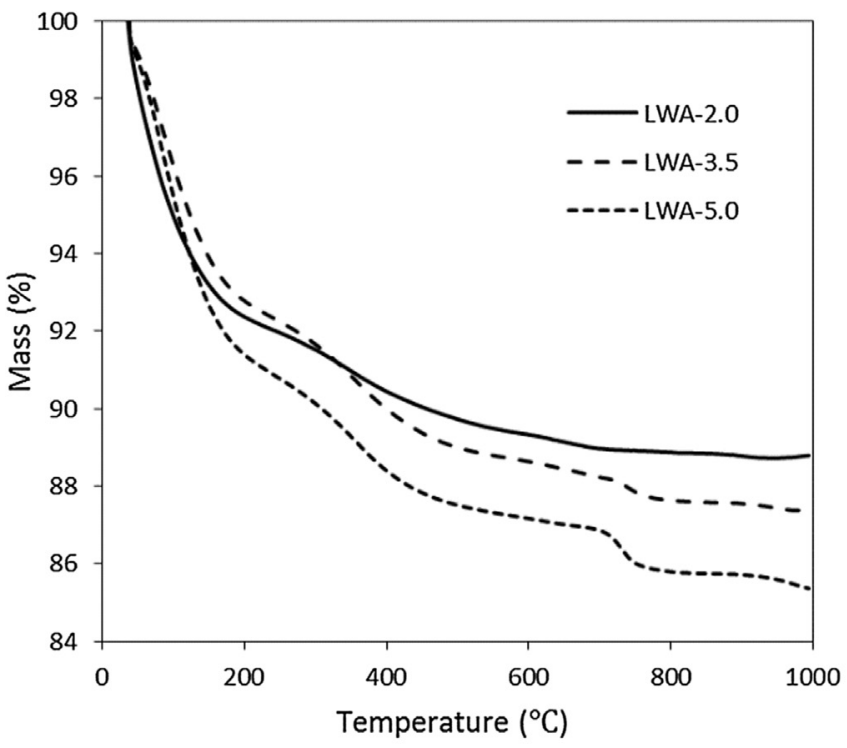

(a) value is $5.4 \%$ in the case of $2.0 \% \mathrm{Na}_{2} \mathrm{O}$, showing a significant reduction. It indicates that besides the delayed reaction process within the first $144 \mathrm{~h}$, the amount of reaction products in $2.0 \% \mathrm{Na}_{2} \mathrm{O}$ mixes after $28 \mathrm{~d}$ of curing is also obviously lower. The mass loss between $600{ }^{\circ} \mathrm{C}$ and $1000{ }^{\circ} \mathrm{C}$ is partly attributed to the decomposition of reaction products, while the carbonates also play a role. A detailed calculation in the temperature range of $600{ }^{\circ} \mathrm{C}$ and $800{ }^{\circ} \mathrm{C}$ shows that when increasing the $\mathrm{Na}_{2} \mathrm{O}$ dosage from $2.0 \%$ to $5.0 \%$, the mass loss in this range is increased from $0.5 \%$ to $1.0 \%$ and then $1.4 \%$, which could be an indication that high alkaline condition contributes to the carbonation of alkali activated materials. The DTG curves shown in Fig. 5(b) present three evident peaks, the one that located around $100{ }^{\circ} \mathrm{C}$ refers to the obvious mass loss of bound water. The shift of this peak to higher temperatures indicates a gel structure with more tightly bound water and finer pore structures [52,53]. The peaks shown between 250 and $450{ }^{\circ} \mathrm{C}$ verify the decomposition of certain reaction products, which are reported to be the dehydration of hydrotalcite that is typically formed from alkali activated slag [54]. The intensity of the peaks around $600{ }^{\circ} \mathrm{C}$ and $800{ }^{\circ} \mathrm{C}$ indicates deferent degrees of carbonation caused by the $\mathrm{Na}_{2} \mathrm{O}$ dosage.

The infrared spectra of the unreacted slag and fly ash, and the reaction products with different $\mathrm{Na}_{2} \mathrm{O}$ contents are shown in Fig. 6. The original slag presents a broad main vibration band at around $900 \mathrm{~cm}^{-1}$, which is attributed to the vibration of terminal Si-O bonds [55]. Another obvious peak at around $670 \mathrm{~cm}^{-1}$ is assigned to the stretching vibration of T-O groups [56]. The unreacted fly ash exhibits several shoulders at around $1080 \mathrm{~cm}^{-1}$ and between 600 and $800 \mathrm{~cm}^{-1}$, which can be attributed to the presence of crystalline phases such as quartz and mullite [57]. The main absorption band at around $1020 \mathrm{~cm}^{-1}$ is assigned to the Si$\mathrm{O}-\mathrm{T}$ bonds with bridge conditions [58]. Upon activation, all mixtures present similar typical absorption bands regardless of the $\mathrm{Na}_{2} \mathrm{O}$ contents. The slight absorption band at $1420 \mathrm{~cm}^{-1}$ confirms the presence of carbonates that are observed from the TG analysis, and the band at $1640 \mathrm{~cm}^{-1}$ indicate the presence of water. All mixes show a main absorption band around $950 \mathrm{~cm}^{-1}$, which is the vibration of a non-bridging $\mathrm{Si}-\mathrm{O}$ bond [59], also commonly recognized as C-A-S-H type gels. The fixed location of the typical bands together with the TG-DTG results indicate that the $\mathrm{Na}_{2} \mathrm{O}$

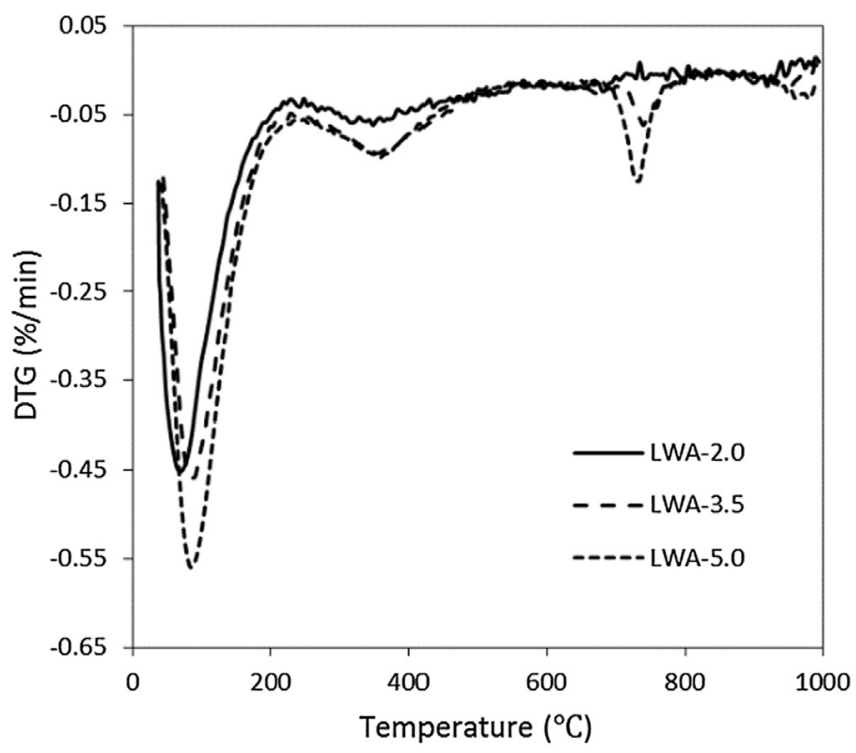

(b)

Fig. 5. TG-DTG analysis of AA slag-fly ash blends with different $\mathrm{Na}_{2} \mathrm{O}$ contents. 


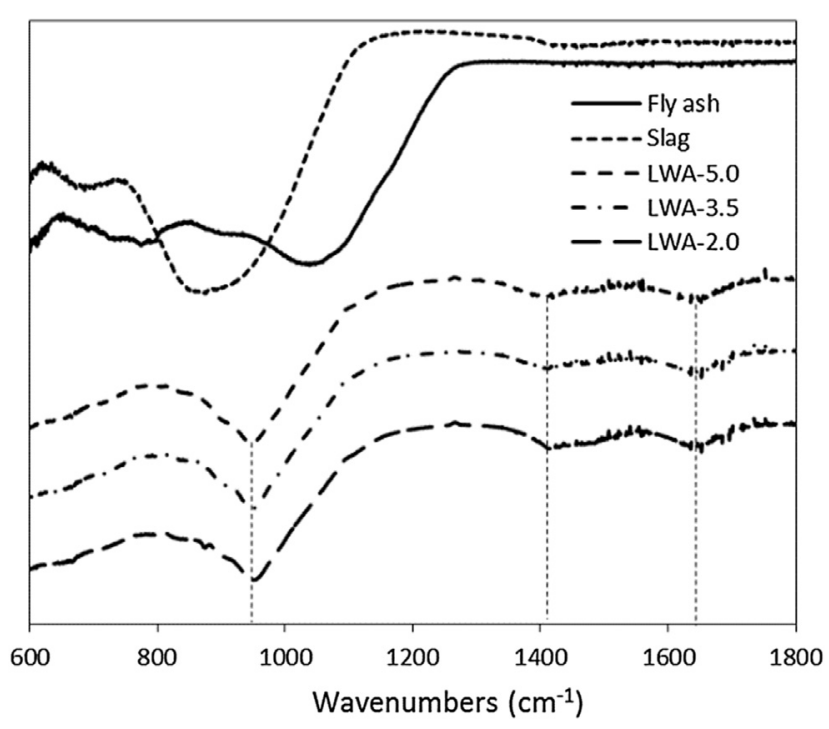

Fig. 6. FTIR spectra of the starting materials and reaction products.

content affects the reaction degree and carbonation behaviours without changing the typical silicate structures within the reaction products.

\subsection{Thermal conductivity}

In terms of the building materials, a low thermal conductivity contributes to an enhanced indoor thermal comfort, saving the energy cost and preventing the fire caused collapses; while lightweight concrete products based on alkali activated materials are capable of achieving those requirements with a further lowered environmental impact. Fig. 7 shows the thermal conductivity of samples with a $\mathrm{Na}_{2} \mathrm{O}$ content of $3.5 \%$ and different density levels used in this study, and a comparison with the available literature [60-63]. A reduction of thermal conductivity with the decrease of the density can be observed in general. For mixtures with a density level of round $1500 \mathrm{~kg} / \mathrm{m}^{3}$, the thermal conductivity (k-value) is $0.37 \mathrm{~W} /(\mathrm{m} \cdot \mathrm{k})$, this value is lower than the ones from the obtained literatures. This is because that besides the density, the differences in matrix composition, type of binder and aggregates also show an influence on the property of thermal insulation $[64,65]$. The ther-

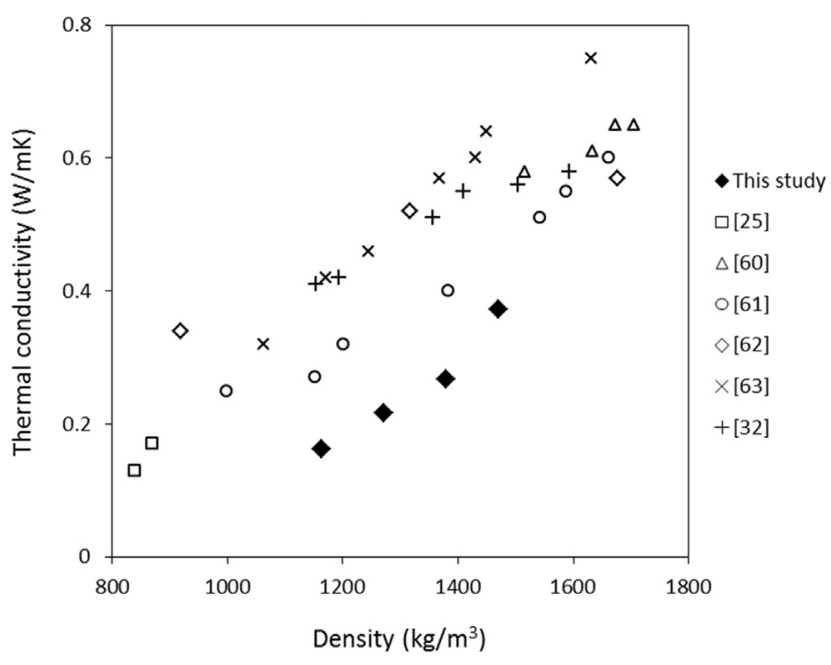

Fig. 7. Thermal conductivity of mixtures with different densities. mal conductivity reduces to $0.29 \mathrm{~W} /(\mathrm{m} \cdot \mathrm{k})$ in samples with a density level of $1400 \mathrm{~kg} / \mathrm{m}^{3}$, with a reduction rate of $21.6 \%$. As can be seen from the mix proportions shown in Table 2, once the $\mathrm{Na}_{2} \mathrm{O}$ content is fixed, the difference between different mixes lies in the aggregate type and dosage. The reduction of density from around 1500 to $1400 \mathrm{~kg} / \mathrm{m}^{3}$ results in a decreased standard sand dosage of $31.6 \%$ by mass, indicating its negative influence on thermal insulation. Further reduction of the density to around 1300 and $1200 \mathrm{~kg} / \mathrm{m}^{3}$ leads to further reduced thermal conductivities of 0.22 and $0.16 \mathrm{~W} /(\mathrm{m} \cdot \mathrm{k})$, respectively. It should be noticed that the thermal conductivity of $0.2 \mathrm{~W} /(\mathrm{m} \cdot \mathrm{k})$ can be classified to the T2 level of thermal insulation products based on the standard of EN 998-1 [66]. It can be seen from Fig. 7 that the thermal conductivity values from this study are lower than that from the literature, which may indicate the advantage of using the alternative binder system together with the lightweight aggregate in this case. Overall, the compressive strengths of around 20-30 MPa together with moderate densities and ideal thermal conductivities indicate a wide and promising application potential of this new lightweight concrete.

\subsection{Acoustical absorption}

Owing to the massive addition of the porous lightweight aggregates, the resulting alkali activated lightweight concrete is expected to exhibit good sound absorption behaviours. Fig. 8 exhibits the sound absorption coefficient as a function of frequency, four mixtures with a $\mathrm{Na}_{2} \mathrm{O}$ content of $3.5 \%$ with different density levels were tested. For instance, the mixture with label of D-15 refers to the sample with a density around $1500 \mathrm{~kg} / \mathrm{m}^{3}$. Generally speaking, the absorption coefficient is significantly increased with the decrease of density, in another word with the increase of lightweight aggregate content within the matrix; and all mixtures mainly show absorption of sound with medium frequencies between around 300 and $1700 \mathrm{~Hz}$. Specifically, mixtures with a density of round $1500 \mathrm{~kg} / \mathrm{m}^{3}$ present a peak absorption coefficient of 0.2 , between 800 and $1000 \mathrm{~Hz}$. The peak absorption coefficient increases to around 0.35 and 0.52 in samples with a density about 1400 and $1300 \mathrm{~kg} / \mathrm{m}^{3}$ respectively, while the main absorption frequency range remains similar. A further reduction of density to around $1200 \mathrm{~kg} / \mathrm{m}^{3}$ results in an increased absorption coefficient to above 0.7 , with shifted main absorption frequency to higher values. In terms of the low frequency and high frequency ranges, this lightweight product shows limited sound absorption effect. It

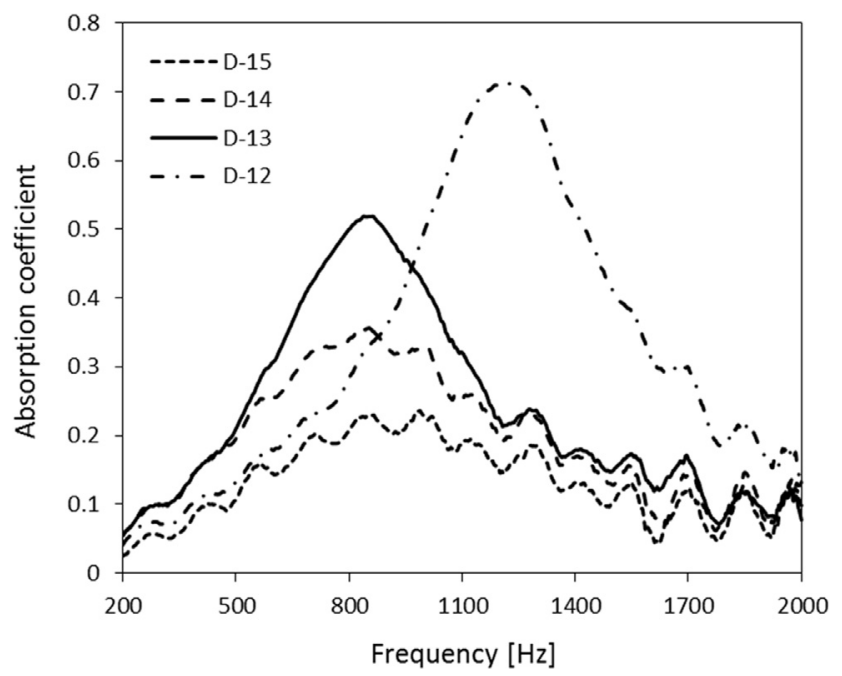

Fig. 8. Acoustic absorption of mixtures with different densities. 
should be mentioned that the medium frequency usually refers to the sound from humans and daily life.

\subsection{SEM analysis}

Scanning electron microscopy images are used to characterize the applied lightweight aggregate and the interfacial transition zones (ITZ) of the reaction products. Due to the fact that the effect of $\mathrm{Na}_{2} \mathrm{O}$ content on micro scale characteristics is not significant, the reaction products shown in Fig. 9 are having a constant $\mathrm{Na}_{2} \mathrm{O}$ content of 3.5\%. Fig. 9-A presents the micro graph of the lightweight aggregate surface, porous structures with irregular shaped surfaces can be observed. This porous structure may already result in a direct link of the aggregate surface and the internal areas. Fig. 9B depicts a sectional view of the internal structure of the lightweight aggregate, micro pores with different sizes and shapes are clearly presented. It is clear that this lightweight aggregate exhibits a high porosity, which would result in excellent thermal insulation
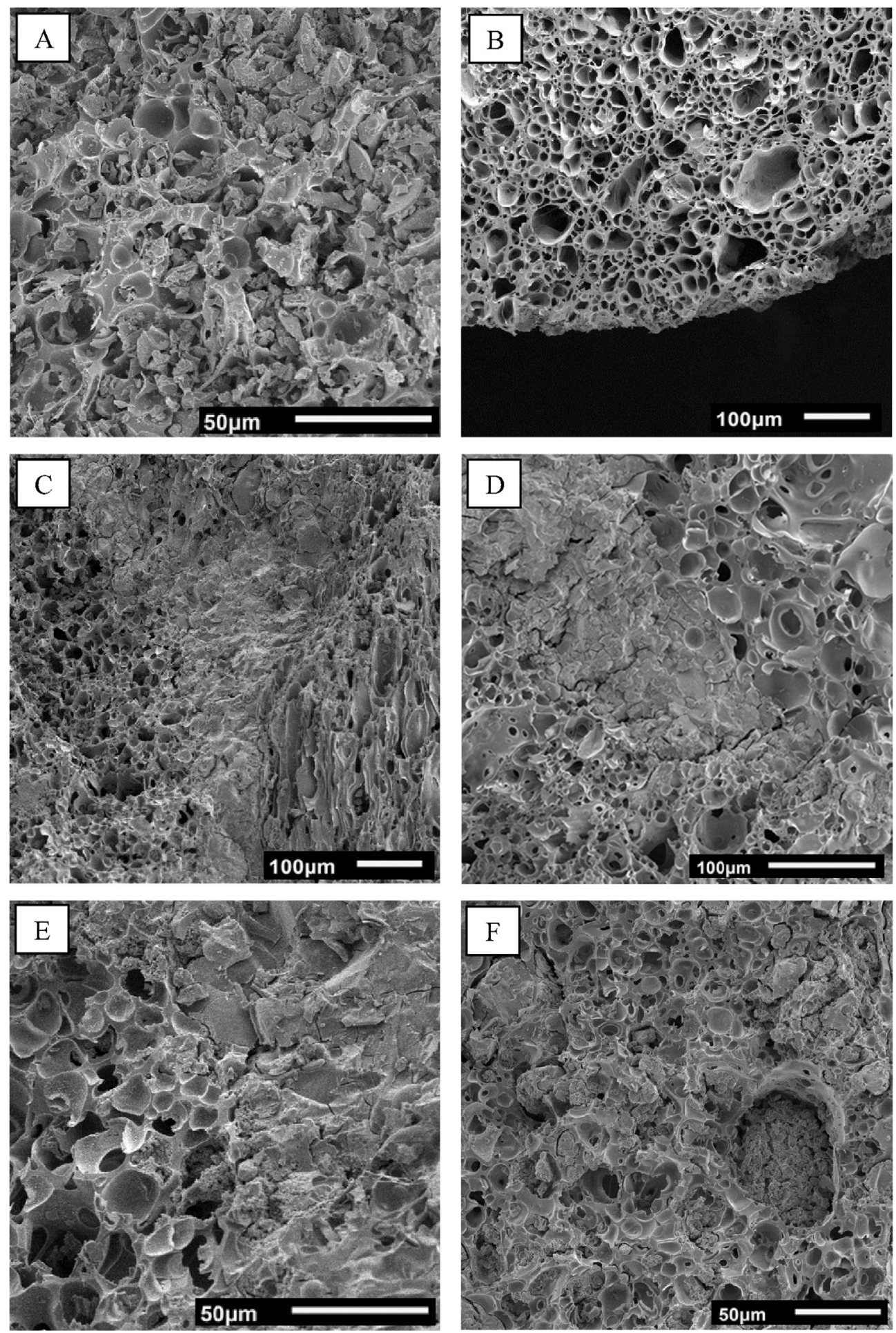

Fig. 9. SEM images of lightweight aggregates and the transition zones. 
Table 3

Calculation on the carbon footprint $\left(\mathrm{kg} / \mathrm{m}^{3}\right)$.

\begin{tabular}{|c|c|c|c|c|c|c|c|}
\hline \multirow[t]{2}{*}{ Sample } & \multirow[t]{2}{*}{ Precursors } & \multicolumn{3}{|l|}{$\begin{array}{l}\text { Activator } \\
\text { (exclude } \mathrm{H}_{2} \mathrm{O} \text { ) }\end{array}$} & \multirow{2}{*}{$\begin{array}{l}\mathrm{CO}_{2} \text { emissions } \\
\text { from } \\
\text { activator }\end{array}$} & \multirow{2}{*}{$\begin{array}{l}\mathrm{CO}_{2} \text { emissions } \\
\text { from } \\
\text { binder }\end{array}$} & \multirow[t]{2}{*}{$\begin{array}{l}\text { Total } \\
\mathrm{CO}_{2} \text { emissions }\end{array}$} \\
\hline & & Olivinenano-s & $\begin{array}{l}\text { Water } \\
\text { glass }\end{array}$ & $\mathrm{NaOH}$ & & & \\
\hline D15-5.0-NS & 384 Slag + 96 Fly ash & 32.5 & 0 & 30.9 & 74.2 & 57.5 & 131.7 \\
\hline D15-5.0-WG & & 0 & 42.3 & 18.3 & 99.1 & & 156.6 \\
\hline D15-3.5-NS & & 22.7 & 0 & 21.7 & 52.0 & & 109.5 \\
\hline D15-3.5-WG & & 0 & 29.6 & 12.8 & 69.3 & & 126.8 \\
\hline D15-2.0-NS & & 13.0 & 0 & 12.4 & 29.7 & & 87.2 \\
\hline D15-2.0-WG & & 0 & 16.9 & 7.3 & 39.6 & & 97.1 \\
\hline Ref-OPC & 480 OPC & 0 & 0 & 0 & 0 & 393.6 & 393.6 \\
\hline
\end{tabular}

and sound absorption properties in macro scale. This sectional view also demonstrates that the micro pores within the aggregate are more like single-direction distributed tube shaped structures, rather than individual spherical ones. The ITZ shown in Fig. 9-C verifies the existence of tube shaped pore structures, as can be seen that two lightweight aggregates that are separated by the binder matrix exhibit different morphology. Together with Fig. 9-D it can be observed that the boundary between aggregate and the pastes is not clearly defined. Fig. 9-E shows that certain amount of reaction products is grown within the porous structures that are close to the ITZ. However it is difficult to identify its effect on the mechanical properties, since on the one hand the reaction products break the original structure of aggregate, while on the other hand the formed reacted gels at those areas strengthen the ITZ by densifying the original porous surface of the aggregates. Lightweight aggregates with smaller particle sizes experience a more evident interaction with the binder matrix, as can be seen from Fig. 9-F that the porous structure of smaller sized lightweight aggregates are partly (sometimes fully) occupied with the reacted gels. This may lead to an increment of the density compared to the designed one, and may slightly reduce the thermal insulation and sound absorption properties.

\subsection{Advantages in carbon footprint}

Applying alkali activated materials shows an advantage in carbon emission towards Portland cement. While within the alkali binder systems, the $\mathrm{Na}_{2} \mathrm{O}$ content is directly linked to the environmental issues. Moreover, the replacement of olivine nano-silica to commercial waterglass will further reduce the overall carbon emission. A calculation on the $\mathrm{CO}_{2}$ footprint of the mixtures used in this study is shown in Table 3. The carbon footprint is usually calculated as the total $\mathrm{CO}_{2}$ emissions in unit volume of concrete. The assumed recipes are based on the mix proportions shown in Table 2. Sample with the label of "D15-5.0-NS" refers to the one with density level of $1500 \mathrm{~kg} / \mathrm{m}^{3}, \mathrm{Na}_{2} \mathrm{O}$ content of $5.0 \%$ and activator type of nano-silica, and "WG" refers to the activator of "water glass". The carbon footprint used in this calculation is 1.915 $\mathrm{tCO}_{2} / \mathrm{t}$ for $\mathrm{NaOH}, 1.514 \mathrm{tCO}_{2} / \mathrm{t}$ for commercial waterglass, 0.82 $\mathrm{tCO}_{2} / \mathrm{t}$ for Portland cement, $0.143 \mathrm{tCO}_{2} / \mathrm{t}$ for slag and $0.027 \mathrm{tCO}_{2} / \mathrm{t}$ for fly ash $[67,68]$. Concerning the olivine nano-silica, a $\mathrm{CO}_{2}$ footprint of $0.461 \mathrm{tCO}_{2} / \mathrm{t}$ is taken from the LCA analysis in VTT (EU F7th project, ProMine internal report) [69], based on an average European industrial case scenario. The values shown above are based on the effective solids contents excluding water.

It can be observed from Table 3 that the carbon emission of Portland cement is few times higher than alkali activated materials; the contribution of $\mathrm{CO}_{2}$ is all from the cement clinkers. In terms of the alkali activated materials, the carbon emission from the binder accounts for around 37-69\% of the overall emissions. When reducing the $\mathrm{Na}_{2} \mathrm{O}$ contents from $5.0 \%$ to $2.0 \%$, the carbon emission from the commercial sodium silicate based activator can be reduced by $60 \%$, such a big reduction of carbon footprint may bring attentions on using suitable $\mathrm{Na}_{2} \mathrm{O}$ dosages and reaching a balance between performances and environmental impact. Moreover, when olivine nano-silica is applied as commercial waterglass replacement, the carbon emission in terms of activator can be further reduced by around $25 \%$. In overall, those reduced carbon emissions from $\mathrm{Na}_{2} \mathrm{O}$ content and alternative silica source provide great potentials for the future mix design and applications.

\section{Conclusions}

This paper evaluates the mechanical properties, thermal property, acoustical absorption and interfacial transition zones of ecofriendly alkali activated slag-fly ash lightweight composites (LWC) with different density classes. The effect of $\mathrm{Na}_{2} \mathrm{O}$ contents and the utilization of alternative silica source on early age reaction, gel characteristics and carbon footprints on the designed LWC are assessed. Mixtures with $28 \mathrm{~d}$ compressive strength up to $32.5 \mathrm{MPa}$ and densities between 1200 and $1500 \mathrm{~kg} / \mathrm{m}^{3}$ are resulted, and a direct correlation between strength and density is observed. The reduction of $\mathrm{Na}_{2} \mathrm{O}$ content from $5 \%$ to $2 \%$ significantly prolongs the reaction process, reduces the content of bound water, hydrotalcite and carbonates, but shows negligible effect on the silicate structure. Compared to the commercial waterglass, the utilization of olivine nano-silica reduces the carbon footprint from activator by around $25 \%$. The lightweight concretes exhibit very low thermal conductivity between 0.16 and $0.37 \mathrm{~W} /(\mathrm{m} \cdot \mathrm{k})$, as well as good sound absorption coefficient up to 0.7 for medium frequencies. The application of alkali activated binders and applying this activator to lightweight concrete suggests an additional approach of preparing construction and building materials with multifunctional properties and greatly reduced environmental impacts.

\section{Conflict of interest}

None.

\section{Acknowledgements}

China Scholarship Council is acknowledged for sponsoring the $\mathrm{PhD}$ research of X. Gao at Eindhoven University of Technology. In addition, thanks are given to J.T. van den Heuvel for helping with the experimental work and to Dr. M. Hornikx for the support with the sound absorption measurement.

\section{References}

[1] Q.L. Yu, P. Spiesz, H.J.H. Brouwers, Development of cement-based lightweight composites, Part 1: Mix design methodology and hardened properties, Cem. Concr. Compos. 44 (2013) 17-29. 
[2] Q.L. Yu, P. Spiesz, H.J.H. Brouwers, Ultra-lightweight concrete: conceptual design and performance evaluation, Cem. Concr. Compos. 61 (2015) 18-28.

[3] EuroLightCon. LWAC material properties state-of-the-art. In: Economic Design and Construction with Light Weight Aggregate Concrete; 1998.

[4] ACI Committee 213. Guide for Structural Lightweight-Aggregate, Concrete; 2003.

[5] P. Friedlingstein, R.A. Houghton, G. Marland, J. Hackler, T.A. Boden, T.J. Conway, et al., Uptake on CO2 emissions, Nat. Geosci. 3 (2010) 811-812.

[6] P. Capros, N. Kouvaritakis, L. Mantzos, Economic evaluation of sectorial emission reduction objectives for climate change top-down analysis of greenhouse gas emission possibilities in the EU. Contribution to a study for DG environment, European Commission, 2001.

[7] B. Yuan, Q.L. Yu, H.J.H. Brouwers, Reaction kinetics, reaction products and compressive strength of ternary activators activated slag designed by Taguchi method, Mater. Des. 86 (2015) 878-886.

[8] D.D. Burduhos Nergis, M.M.A.B. Abdullah, P. Vizureanu, The effect of fly ash/ alkaline activator ratio in class F fly ash based geopolymers, Eur. J. Mater. Sci. Eng. 2 (4) (2019) 111-118.

[9] A.M. Rashad, A comprehensive overview about the influence of different additives on the properties of alkali-activated slag-A guide for Civil Engineer, Constr. Build. Mater. 47 (2013) 29-55.

[10] D.M.A. Huiskes, A. Keulen, Q.L. Yu, H.J.H. Brouwers, Design and performance evaluation of ultra-lightweight geopolymer concrete, Mater. Des. 89 (2016) 516-526.

[11] D. Panias, V. Vaou, Thermal insulating foamy geopolymers from perlite, Miner. Eng. 23 (2010) 1146-1151.

[12] P. Posi, C. Teerachanwit, C. Tanutong, S. Limkamoltip, S. Lertnimoolchai, V. Sata, P. Chindaprasirt, Lightweight geopolymer concrete containing aggregate from recycle lightweight block, Mater. Des. 52 (2013) 580-586.

[13] K. Lee, J. Song, M. Gong, K. Yang, Properties and sustainability of alkaliactivated slag foamed concrete, J. Cleaner Prod. 68 (2014) 226-233.

[14] J.I. Escalante, O. Burciaga, R. Aguilar, Lightweight concretes of activated metakaolin-fly ash binders, with blast furnace slag aggregates, Constr. Build. Mater. 24 (2010) 1166-1175.

[15] W.M.W. Ibrahim, K. Hussin, M.M.A. Abdullah, A.A. Kadir, L.M. Deraman, A.V. Sandu, Influence of foaming agent/water ratio and foam/geopolymer paste ratio to the properties of fly ash-based lightweight geopolymer for brick application, Rev. Chim. 68 (9) (2017) 1978-1982.

[16] M.M.A. Abdullah, M.F.M. Tahir, K. Hussin, M. Binhussain, I.G. Sandu, Z. Yahya, A.V. Sandu, Fly ash based lightweight geopolymer concrete using foaming agent technology, Rev. Chim. 66 (7) (2015) 1001-1003.

[17] A.M.M. Al Bakri, H. Kamarudin, I.K. Nizar, A.V. Sandu, M. Binhussain, Y. Zarina, A.R. Rafiza, Design, Processing and characterization of fly ash-based geopolymers for lightweight concrete application, Rev. Chim. 64 (4) (2013) 382-387.

[18] A.R. Brough, A. Atkinson, Sodium silicate-based alkali-activated slag mortars: Part I. Strength, hydration and microstructure, Cem. Concr. Res. 32 (2002) 865-879.

[19] Li Chao, H.H. Sun, L. Li, A review: the comparison between alkali-activated slag $(\mathrm{Si}+\mathrm{Ca})$ and metakaolin $(\mathrm{Si}+\mathrm{Al})$ cements, Cem. Concr. Res. 40 (2010) 13411349.

[20] N.K. Lee, H.K. Lee, Setting and mechanical properties of alkali-activated fly ash/ slag concrete manufactured at room temperature, Constr. Build. Mater. 47 (2013) 1201-1209.

[21] M. Rashad Alaa, Properties of alkali-activated fly ash concrete blended with slag, Iran. J. Mater. Sci. Eng. 10 (1) (2013) 57-64.

[22] S. Aydin, A ternary optimization of mineral additives of alkali activated cement mortars, Constr. Build. Mater. 43 (2013) 131-138.

[23] T. Sugama, L.E. Brothers, T.R. Van de Putte, Acid-resistant cements for geothermal wells: sodium silicate activated slag/fly ash blends, Adv. Cem. Res. 17 (2) (2005) 65-75.

[24] X. Gao, Q.L. Yu, H.J.H. Brouwers, Characterization of alkali activated slag-fly ash blends containing nano-silica, Constr. Build. Mater. 98 (2015) 397-406.

[25] M. Chi, R. Huang, Binding mechanism and properties of alkali-activated fly ash/slag mortars, Constr. Build. Mater. 40 (2013) 291-298.

[26] F. Puertas, S. Martínez-Ramírez, S. Alonso, E. Vázquez, Alkali-activated fly ash/ slag cement. Strength behaviour and hydration products, Cem. Concr. Res. 30 (2000) 1625-1632.

[27] S.A. Bernal, J.L. Provis, V. Rose, A. Mejía de Gutierrez, Evolution of binder structure in sodium silicate-activated slag-metakaolin blends, Cem. Concr. Compos. 33 (2011) 46-54.

[28] X. Gao, Q.L. Yu, H.J.H. Brouwers, Assessing the porosity and shrinkage of alkali activated slag-fly ash composites designed applying a packing model, Constr. Build. Mater. 119 (2016) 175-184.

[29] S.A. Bernal, E.D. Rodriguez, R.M. Gutierrez, J.L. Provis, S. Delvasto, Activation of metakaolin/slag blends using alkaline solutions based on chemically modified silica fume and rice husk ash, Waste Biomass Valor. 3 (2012) 99-108.

[30] P. Duxson, J.L. Provis, G.C. Lukey, S.W. Mallicoat, W.M. Kriven, J.S.J. Deventer, Understanding the relationship between geopolymer composition, microstructure and mechanical properties, Colloids Surf., A 269 (2005) 47-58.

[31] European Commission. Reference Document on Best Available Techniques for the Manufacture of Large Volume Inorganic Chemicals - Solids and Others Industry, 2007.

[32] A. Lazaro, H.J.H. Brouwers, G. Quercia, J.W. Geus, The properties of amorphous nano-silica synthesized by the dissolution of olivine, Chem. Eng. J. 211 (2012) $112-121$.
[33] A. Lazaro, G. Quercia, H.J.H. Brouwers, J.W. Geus, Synthesis of a green nanosilica material using beneficiated waste dunites and its application in concrete, World J. Nano Sci. Eng. 3 (2013) 41-51.

[34] R.C.L. Jonckbloedt, The Dissolution of Olivine in Acid, A Cost Effective Process for the Elimination of Waste Acids ( PhD Thesis), Utrecht University, 1997.

[35] X. Gao, Q.L. Yu, H.J.H. Brouwers, Reaction kinetics, gel character and strength of ambient temperature cured alkali activated slag-fly ash blends, Constr. Build. Mater. 80 (2015) 105-115.

[36] X. Gao, Q.L. Yu, H.J.H. Brouwers, Properties of alkali activated slag-fly ash blends with limestone addition, Cem. Concr. Compos. 59 (2015) 119-128.

[37] British Standard EN 196-1:2005. Methods of Testing Cement Part 1: Determination of Strength.

[38] EN 12667: 2001. Thermal Performance of Building Materials and Products Determination of Thermal Resistance by Means of Guarded Hot Plate and Heat Flow Meter Methods - Products of High and Medium Thermal Resistance.

[39] EN 10534-1:2003. Acoustics - Determination of Sound Absorption Coefficient and Impedance in Impedance Tubes - Part 2: Transfer-Function Method.

[40] Zareef MAM. Conceptual and Structural Design of Buildings Made of Lightweight and Infra-Lightweight Concrete (Berlin) 2010.

[41] J. Alduaij, K. Alshaleh, M. Naseerd, K. Ellaithy, Lightweight concrete in hot coastal areas, Cem. Concr. Compos. 21 (1999) 453-458.

[42] M. Schauerte, R. Trettin, Neue Schaumbetone mit Gesteigerten Mehanischen ind Physikalischen Eigenschaften, Weimar, Germany, 2012.

[43] D. Kralj, Experimental study of recycling lightweight concrete with aggregates containing expanded glass, Process Saf. Environ. Prot. 87 (2009) 267-273.

[44] X. Liu, K.S. Chia, M.H. Zhang, Development of lightweight concrete with high resistance to water and chloride-ion penetration, Cem. Concr. Compos. 32 (2010) 757-766.

[45] Y. Xu, L. Jiang, J. Xu, Y. Li, Mechanical properties of expanded polystyrene lightweight aggregate concrete and brick, Constr. Build. Mater. 27 (2012) 32 38.

[46] C.C. Yang, R. Huang, Approximate strength of lightweight aggregate using micromechanics method, Adv. Cem. Based Mater. 7 (1998) 133-138.

[47] N.U. Kockal, T. Ozturan, Strength and elastic properties of structural lightweight concretes, Mater. Des. 32 (2011) 2396-2403.

[48] E. Deira, B.S. Gebregziabiher, S. Peethamparan, Influence of starting material on the early age hydration kinetics, microstructure and composition of binding gel in alkali activated binder systems, Cem. Concr. Compos. 48 (2014) 108117.

[49] S. Chithiraputhiran, N. Neithalath, Isothermal reaction kinetics and temperature dependence of alkali activation of slag, fly ash and their blends, Constr. Build. Mater. 45 (2013) 233-242.

[50] C. Shi, R.L. Day, A calorimetric study of early hydration of alkali-slag cements, Cem. Concr. Res. 25 (1995) 1333-1346.

[51] L. Alarcon-Ruiz, G. Platret, E. Massieu, A. Ehrlacher, The use of thermal analysis in assessing the effect of temperature on a cement paste, Cem. Concr. Res. 35 (2005) 609-613.

[52] B.E.I. Abdelrazig, S.D. Main, D.V. Nowell, Hydration studies of modified OPC pastes by differential scanning calorimetry and thermogravimetry, J. Therm. Anal. 38 (1992) 495-504.

[53] T. Nochaiya, W. Wongkeo, K. Pimraksa, A. Chaipanich, Microstructural, physical, and thermal analyses of Portland cement-fly ash-calcium hydroxide blended pastes, J. Therm. Anal. Calorim. 100 (2010) 101-108.

[54] M. Ben Haha, B. Lothenbach, G. Le Saout, F. Winnefeld, Influence of slag chemistry on the hydration of alkali-activated blast-furnace slag - Part I: Effect of MgO, Cem. Concr. Res. 41 (9) (2011) 955-963.

[55] Z.H. Zhang, H. Wang, J.L. Provis, F. Bullen, A. Reid, Y.C. Zhu, Quantitative kinetic and structural analysis of geopolymers. Part 1. The activation of metakaolin with sodium hydroxide, Therm Acta 539 (2012) 23-33.

[56] G. Kovalchuk, A. Fernandez-Jimenez, A. Palomo, Alkali-activated fly ash: Effect of thermal curing conditions on mechanical and microstructural development - Part II, Fuel 86 (2007) 315-322.

[57] M. Criado, A. Fernandez-Jimenez, A. Palomo, Alkali activation of fly ash: Effect of the SiO2/Na2O ratio Part I: FTIR study, Microporous Mesoporous Mater. 106 (2007) 180-191.

[58] A. Hajimohammadi, J.L. Provis, J.S.J. Deventer, Time-resolved and spatially resolved infrared spectroscopic observation of seeded nucleation controlling geopolymers gel formation, J. Colloid Interface Sci. 357 (2011) 384-392.

[59] E.W. Claire, L.D. Luke, H. Monika, P. Katharine, Intrinsic differences in atomic ordering of calcium (alumino) silicate hydrates in conventional and alkaliactivated cements, Cem. Concr. Res. 67 (2015) 66-73.

[60] S. Real, M.G. Gomes, A.M. Rodrigues, J.A. Bogas, Contribution of structural lightweight aggregate concrete to the reduction of thermal bridging effect in buildings, Constr. Build. Mater. 121 (2016) 460-470.

[61] S.K. Lu, O.S. Man, S.S. Xing, X.L. Yun, Research on several physicomechanical properties of lightweight aggregate concrete, Int. J. Lightweight Concr. 2 (1980) 185-191.

[62] O. Sengul, S. Azizi, F. Karaosmanoglu, M.A. Tasdemir, Effect of expanded perlite on the mechanical properties and thermal conductivity of lightweight concrete, Energy Build. 43 (2011) 671-676.

[63] FIP, Manual of Lightweight Aggregate Concrete, second ed., FIP, Surrey University Press, Glasgow, UK, 1983.

[64] A.C.J. De Korte, H.J.H. Brouwers, Calculation of thermal conductivity of gypsum plasterboards at ambient and elevated temperature, Fire Mater. 34 (2010) 5575. 
[65] P. Zehner, E.U. Schlunder, Thermal conductivity of granular materials at moderate temperatures, Chem. Ing. Tech. 42 (1970) 933-941.

[66] EN 998-1, Specification for Mortar for Masonry. Rendering and Plastering Mortar, CEN, 2010.

[67] F. Collins, Inclusion of carbonation during the life cycle of built and recycle concrete: influence on their carbon footprint, Int. J. Life Cycle Assess. 15 (2010) 549-556.
[68] L.K. Turner, F.G. Collins, Carbon dioxide equivalent (CO2-e) emissions: a comparison between geopolymer and OPC cement concrete, Constr. Build. Mater. 43 (2013) 125-130.

[69] EU FP7 Project ProMine: Nanoparticle Products from New Mineral Resources in Europe (Grant agreement No. 228559).

[70] EN 206-1, Concrete - Part 1: Specification, Performance, Production and Conformity, CEN, 2000. 